\title{
Prevalence and clinical implications of the TP53 p.R337H mutation in Brazilian breast cancer patients: a systematic literature review
}

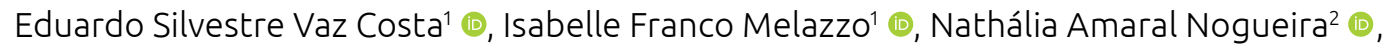

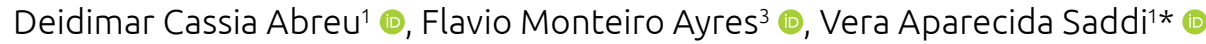

\section{ABSTRACT}

This study assessed the prevalence and clinical implications of the TP53 p.R337H mutation in Brazilian breast cancer patients through a systematic literature review. The literature review was performed in the PubMed, Scientific Electronic Library Online (SciELO), and Medical Literature Analysis and Retrieval System Online (MEDLINE) databases from 1997 to 2018. We used the keyword "R337H" in the search since it resulted in the largest number of published articles on the subject. Initially, we found 75 articles, and, after reviewing the titles and abstracts, we selected 18 studies investigating the prevalence of the TP53 p.R337H mutation in breast cancer patients and its clinical implications. The reading of the full texts led to the inclusion of seven studies. The studies were carried out in the states of São Paulo, Rio Grande do Sul, Rio de Janeiro, and Bahia. The TP53 p.R337H mutation was detected in 87 (4.8\%) of the 1.789 women with breast cancer investigated. The prevalence of the TP53 p.R337H mutation in the selected studies ranged from 0.5 to $8.6 \%$. These findings highlight the recommendation for screening the R337H variant in breast cancer patients in Brazil and suggest the need for new research addressing the clinical and prognostic aspects of breast cancer patients with TP53 p.R337H mutation-positive.

KEYWORDS: genes, P53; cancer; mutation.

\section{INTRODUCTION}

Breast cancer is an important public health problem, with high incidence in Brazil and worldwide. The study of breast carcinogenesis and risk factors for breast cancer is relevant to disease management, and numerous genes involved in the process of breast carcinogenesis have been identified.

Changes in the TP53 pathway are significant in the pathogenesis of several human cancers ${ }^{1}$. In breast cancer, TP53 mutations are found in $30-35 \%$ of primary invasive tumors. However, the prevalence of mutations varies depending on the histological type of the disease, being found in up to $80 \%$ of triple-negative (TN) breast cancer, $10 \%$ of luminal A, $30 \%$ of luminal B, and in up to $70 \%$ of tumors rich in human epidermal growth factor receptor 2 (HER2) ${ }^{2-4}$. In Brazil, a TP53 mutation called p.R337H draws the attention of professionals who deal with breast cancer, as it has been identified in a significant portion of patients with this type of cancer ${ }^{5}$.

The tumor suppressor gene TP53, located on the short arm of chromosome 17 (17p13.1), encodes a nuclear phosphoprotein of 53 kilodaltons $(\mathrm{kDa})$, which is responsible for regulating the expression of several genes that control the progression of the cell cycle, angiogenesis, and apoptosis, working as a transcription factor ${ }^{6}$. In normal cells, p53 is expressed at baseline levels. Nevertheless, when cells are exposed to agents that cause damage to the deoxyribonucleic acid (DNA), p53 expression increases and initiates transcriptional control of several target genes that prevent the cell cycle progression. Cell cycle

${ }^{1}$ Pontifícia Universidade Católica de Goiás - Goiânia (GO), Brazil.

¿Universidade Federal de Goiás - Goiânia (GO), Brazil.

${ }^{3}$ Universidade Estadual de Goiás - Goiânia (GO), Brazil.

*Corresponding author: verasaddi@gmail.com

Conflict of interests: nothing to declare.

Received on: 08/22/2019. Accepted on: 12/11/2019. 
blockage allows repair of cell damage, preventing replication of DNA lesions potentially involved in tumor induction, as well as the division of abnormal cells. In the case of extensive genomic involvement, p53 induces cell death due to apoptosis, preventing the spread of genetic changes?

Several functions are attributed to the $\mathrm{p} 53$ protein in the regulation of cellular response to genotoxic stress, such as that caused by ionizing radiation, free radicals, hypoxia, among others, as well as oncogene inactivation. The p53 protein also acts in the process of angiogenesis, cellular senescence, and inflammatory response $^{8}$. The ability to recognize DNA damage and regulate the cell cycle closely connects the $\mathrm{p} 53$ protein to tumor suppression and cancer biology 9 . The p53 pathway can be influenced in several ways, either by the presence of somatic and germline mutations or by the presence of genetic polymorphisms. Several genes are involved in this cell regulation pathway, so a large spectrum of polymorphisms and mutations leads to individual variations in tumor phenotypes.

Mutations that change the function of the protein encoded by the TP53 gene, preventing its tumor suppressor activity, are widely described ${ }^{9}$. One of them, called p.R337H, was first identified in Brazil among children with adrenocortical tumors in families without a family history of cancer ${ }^{10}$. The mutation located in exon 10 of the TP53 gene, codon 337, consists of exchanging guanine (CGC) for adenine (CAC), which results in the replacement of the amino acid arginine (R) for histidine $(\mathrm{H})$ at position 337 of the protein ${ }^{11}$. The mutated allele encodes a protein with changes in the C-terminal domain, producing unstable p53 tetramers, which compromise its tumor suppressor function ${ }^{12}$. The biochemical repercussion of this mutation affects the ability of p53 to form oligomers. The formation of oligomers depends on an optimal $\mathrm{pH}$, and acid-base changes in the amino acid sequence of p53 affect its biochemical properties ${ }^{12}$. At pH 7, the ability to form oligomers does not change, but in a slightly basic medium, oligomer formation is impaired ${ }^{13}$. Given this theory, several phenotypic variations present in families carrying the TP53 p.R337H mutation are described ${ }^{14}$.

In Brazil, the TP53 p.R337H mutation was initially detected in the Southern Region in individuals considered unrelated, but who later had their common ancestry elucidated ${ }^{15}$. The historical hypothesis explains the spread of the TP53 p.R337H mutation by proposing that the opening of Estrada dos Tropeiros, a highway between São Paulo and the south of the country, led to the migration and distribution of TP53 p.R337H carriers to the South and Southeast regions of Brazil, which characterized the so-called founder effect ${ }^{16}$.

Some studies ${ }^{17}$ have investigated the prevalence of the TP53 p.R337H mutation in Brazilian women with breast cancer. However, when comparing the different regions of the country, there are variations in prevalence and a higher concentration of studies in the South and Southeast regions. The penetrance of the TP53 p.R337H mutation is still poorly understood in Brazil, as well as its clinical implications in breast cancer. The TP53 p.R337H mutation has proven to be relevant in the epidemiological context of cancer in Brazil, but few updated studies assess the prevalence and clinical implications of the mutation in the Brazilian population, especially for breast cancer ${ }^{17}$. Also, studies are concentrated in the South and Southeast of the country, while frequencies in other regions remain unknown.

This study comprises a systematic literature review that investigated the prevalence of the TP53 p.R337H mutation in women with breast cancer in Brazil, as well as the association of the mutation with clinical implications of tumors. Given the relevance of the TP53 p.R337H mutation in the current Brazilian scenario, this study can help oncology professionals in the clinical management of patients with the mutation and their families, as well as guide the development of new studies that address this issue.

\section{METHODS}

\section{Search strategy}

The bibliographic review was carried out in the PubMed, Scientific Electronic Library Online (SciELO), and Medical Literature Analysis and Retrieval System Online (MEDLINE) databases, from 1997 to 2018. We used the keyword "R337H" in the search, as it resulted in the largest number of published studies on the subject. The search was limited to articles published in Portuguese, English, and Spanish. Two researchers reviewed the titles and abstracts of the articles retrieved in the initial search to determine their relevance. Disagreements in the selection and inclusion of studies were solved by a meeting, re-reading, and discussion with a third researcher.

\section{Eligibility criteria}

The articles chosen were considered eligible when they met the following inclusion criteria:

- articles investigating the prevalence of the TP53 p.R337H mutation in Brazilian women with breast cancer;

- articles studying the influence of the TP53 p.R337H mutation as a marker in the prognosis of breast cancer patients with this alteration;

- studies associating the TP53 p.R337H mutation with the risk of developing breast cancer;

- primary and descriptive studies;

- articles presenting a clearly described methodology;

- studies with consistent objectives regarding the methodology;

- articles in Portuguese,English, and Spanish fully available online.

According to the exclusion criteria, the following studies were not eligible: 
- publications in languages other than Portuguese, English, and Spanish;

- $\quad$ studies with repeated cases;

- articles investigating other TP53 mutations in Brazilian breast cancer patients;

- case reports and systematic literature reviews.

\section{Data extraction and analysis}

We extracted the following study data: title, first author, year of publication, study objective, population studied, number of participants, type of sample investigated, case origin, molecular methods of mutation assessment, and main results. The data obtained were reviewed and synthesized in tables.

\section{RESULTS}

\section{Study selection}

Initially, we found 75 studies by electronic data search. After reviewing the titles and abstracts of these articles, we selected 18 studies that investigated the prevalence of the TP53 p.R337H mutation in breast cancer patients and its clinical implications. Reading the full texts of these articles resulted in the exclusion of 11 studies. In total, seven articles were eligible for the systematic review. Figure 1 shows the flowchart of the study selection process.

\section{Characteristics of included studies}

The seven studies included in this systematic review evaluated a total of 2,456 patients with and without breast cancer, with and without the TP53 p.R337H mutation. The number of patients analyzed in the different studies ranged from 28 to 874 , and the included studies were carried out in the states of São Paulo, Rio de Janeiro, Rio Grande do Sul, and Bahia. São Paulo and Rio Grande do Sul were the states that most researched the subject. The oldest article was published in 2008, and the newest is from 2014. All seven studies were published in English. Table 1 presents the characteristics of the studies included in the systematic review.

The mutation assessment methods in the selected studies included: polymerase chain reaction (PCR) associated with the analysis of restriction fragment length polymorphism (RFLP), comparative genomic hybridization based on microarrays (CGH-array), gene sequencing, high-resolution melting (HRM), immunohistochemistry (IHC), and real-time PCR (qPCR), using TaqMan probes. The study that used immunohistochemistry assessed p53 protein expression for the presence of the $\mathrm{R} 337 \mathrm{H}$ mutation in tumor specimens. In general, the most adopted mutation analysis method was PCR-RFLP, in three studies, while the qPCR method was used in two studies, and gene sequencing was used to confirm the detected mutations.
All studies included in the analysis investigated the TP53 p.R337H mutation in blood samples (Table 1), except one ${ }^{18}$, which investigated the mutation only in specimens of phyllodes tumors. Two studies ${ }^{19,20}$ that examined TP53 p.R337H in blood samples also investigated the mutation in tumor samples.

\section{Prevalence of TP53 p.R337H mutation in Brazilian women with breast cancer}

Seven studies investigated the prevalence of the TP53 p.R337H mutation in a total of 1,789 women with breast cancer, of whom 87 (4.8\%) had the TP53 p.R337H mutation (Table 2). The frequencies of the TP53 p.R337H mutation in the selected studies ranged from $0.5^{21}$ to $8.6 \%{ }^{20}$.

Among the selected studies, three were control cases ${ }^{19,21,22}$, and they assessed the prevalence of the TP53 p.R337H mutation in 1,208 women - 541 with breast cancer and 667 without breast cancer. The TP53 p.R337H mutation was detected in seven of 541 patients in the case group (1.3\%) and no woman in the control

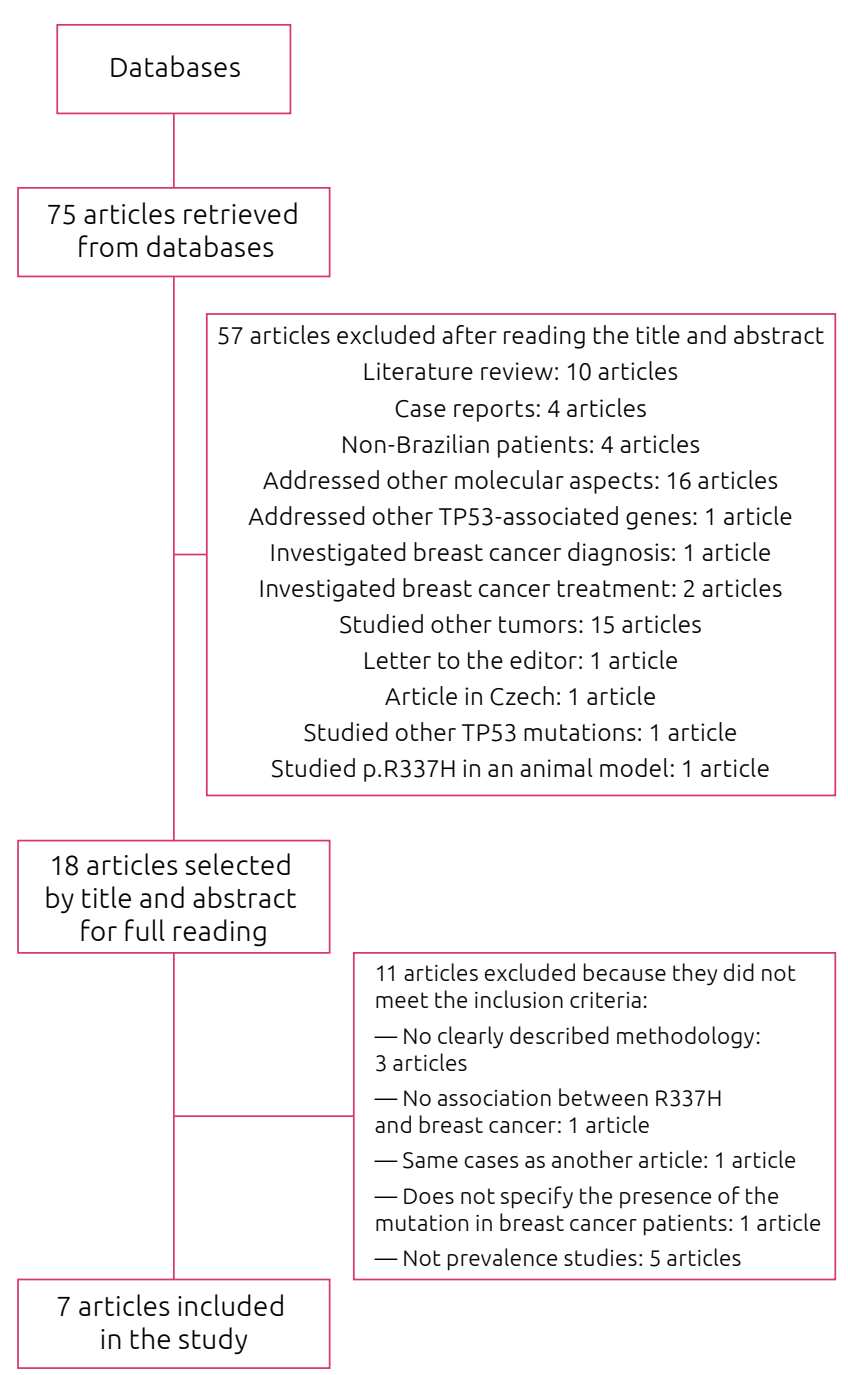

Figure 1. Flowchart of the study selection process. 
Table 1. Characteristics of the studies included in the systematic review.

\begin{tabular}{|c|c|c|c|c|}
\hline Reference & Case Origin & Objective/Sampling & $\begin{array}{c}\text { Analyzed Biological Material/ } \\
\text { Method }\end{array}$ & Results \\
\hline Silva et al., $2014^{14}$ & $\begin{array}{c}\text { São Paulo, SP, } \\
\text { Brazil }\end{array}$ & $\begin{array}{l}\text { To investigate genetic changes } \\
\text { in a group of } 120 \text { women with } \\
\text { hereditary breast and ovarian } \\
\text { cancer (HBOC) syndrome. }\end{array}$ & $\begin{array}{l}\text { Blood. CGH-array and real-time } \\
\text { PCR for mutation detection. }\end{array}$ & $\begin{array}{l}\text { Three out of } 120 \text { women } \\
\text { with breast cancer had the } \\
\text { TP53 p.R337H mutation. }\end{array}$ \\
\hline $\begin{array}{l}\text { Giacomazzi } \\
\text { et al., } 2013^{18}\end{array}$ & $\begin{array}{l}\text { Porto Alegre, RS, } \\
\text { Brazil; Barretos, } \\
\text { SP, Brazil }\end{array}$ & $\begin{array}{l}\text { To assess the presence of the } \\
\text { TP53 p. R337H mutation in } 148 \\
\text { women with phyllodes tumor. }\end{array}$ & $\begin{array}{l}\text { Tumor sample. Real-time PCR/ } \\
\text { TaqMan and DNA sequencing. }\end{array}$ & $\begin{array}{l}\text { Eight out of } 148 \text { women } \\
\text { had the TP53 p.R337H } \\
\text { mutation, three with a } \\
\text { malignant tumor and five } \\
\text { with a benign tumor. }\end{array}$ \\
\hline $\begin{array}{l}\text { Assumpção } \\
\text { et al., } 2008^{19}\end{array}$ & $\begin{array}{c}\text { Campinas, SP, } \\
\text { Brazil }\end{array}$ & $\begin{array}{c}\text { To determine the prevalence of } \\
\text { the TP53 p.R337H mutation in } \\
123 \text { women with breast cancer } \\
\text { and } 223 \text { control women without } \\
\text { breast cancer. }\end{array}$ & $\begin{array}{c}\text { Blood and tumor sample. PCR- } \\
\text { RFLP and IHC to detect the } \\
\text { mutated protein. }\end{array}$ & $\begin{array}{l}\text { Three out of } 123 \text { women } \\
\text { with breast cancer } \\
\text { had the TP53 p.R337H } \\
\text { mutation, and no women } \\
\text { in the control group had } \\
\text { the mutation. }\end{array}$ \\
\hline $\begin{array}{l}\text { Giacomazzi } \\
\text { et al., } 2014^{20}\end{array}$ & $\begin{array}{c}\text { Porto Alegre, RS, } \\
\text { Brazil }\end{array}$ & $\begin{array}{l}\text { To assess the prevalence of the } \\
\text { TP53 p.R337H mutation in a group } \\
\text { of } 874 \text { women with breast cancer. }\end{array}$ & $\begin{array}{l}\text { Blood and tumor sample. Real- } \\
\text { time PCR/TaqMan for mutation } \\
\text { detection, DNA sequencing, and } \\
\text { PCR-RFLP for tumor tissue analysis. }\end{array}$ & $\begin{array}{l}\text { Out of the } 874 \text { breast } \\
\text { cancer patients, } 72 \text { had the } \\
\text { TP53 p.R337H mutation. }\end{array}$ \\
\hline $\begin{array}{l}\text { Gomes et al., } \\
2012^{21}\end{array}$ & $\begin{array}{l}\text { Rio de Janeiro, } \\
\text { RJ, Brazil }\end{array}$ & $\begin{array}{l}\text { To assess the prevalence of the } \\
\text { TP53 p.R337H mutation in } 390 \\
\text { women with breast cancer and } 324 \\
\text { controls without breast cancer. }\end{array}$ & $\begin{array}{c}\text { Blood. Allele-specific PCR } \\
\text { (amplification refractory } \\
\text { mutation system - ARMS) and } \\
\text { DNA sequencing. }\end{array}$ & $\begin{array}{c}\text { Two out of the } 390 \\
\text { women in the case group } \\
\text { had the TP53 p.R337H } \\
\text { mutation. No woman in } \\
\text { the control group had } \\
\text { the mutation. }\end{array}$ \\
\hline $\begin{array}{l}\text { Cury et al., } \\
2014^{22}\end{array}$ & $\begin{array}{l}\text { Ribeirão Preto, } \\
\text { SP, Brazil }\end{array}$ & $\begin{array}{l}\text { To investigate the prevalence of } \\
\text { the TP53 p.R337H mutation in } \\
28 \text { women with HBOC and } 120 \\
\text { controls without cancer. }\end{array}$ & $\begin{array}{l}\text { Blood. High resolution melting } \\
\text { (HRM) for mutation detection. }\end{array}$ & $\begin{array}{l}\text { Two out of } 28 \text { women } \\
\text { with breast cancer } \\
\text { had the TP53 p.R337H } \\
\text { mutation. No woman in } \\
\text { the control group had } \\
\text { the mutation. }\end{array}$ \\
\hline $\begin{array}{l}\text { Felix et al., } \\
2014^{24}\end{array}$ & $\begin{array}{l}\text { Salvador, BA, } \\
\text { Brazil }\end{array}$ & $\begin{array}{c}\text { To investigate mutations in } 106 \\
\text { women with HBOC. }\end{array}$ & $\begin{array}{l}\text { Blood. Allele-specific PCR, PCR- } \\
\text { RFLP, and DNA sequencing. }\end{array}$ & $\begin{array}{c}\text { One out of } 106 \text { women } \\
\text { with HBOC had the TP53 } \\
\text { p.R337H mutation. }\end{array}$ \\
\hline
\end{tabular}

PCR: polymerase chain reaction; DNA: deoxyribonucleic acid; RFLP: restriction fragment length polymorphism; CGH-array: comparative genomic hybridization based on microarrays; IHC: immunohistochemistry.

Table 2. Studies that investigated the prevalence of the TP53 p.R337H mutation in Brazilian patients with breast cancer (BC).

\begin{tabular}{|c|c|c|c|c|c|}
\hline Reference & $\mathbf{N}$ & $\begin{array}{l}\text { Inclusion } \\
\text { criteria }\end{array}$ & $\begin{array}{l}\text { Investigated } \\
\text { gene region }\end{array}$ & Mutation screening method & $\begin{array}{c}\text { N (\%) } \\
\text { p.R337H }\end{array}$ \\
\hline Giacomazzi et al., 2014²0 & 59 & High-risk BC & TP53 p.R337H & qPCR TaqMan, sequencing, and PCR-RFLP & $2(3.4 \%)$ \\
\hline Giacomazzi et al., 2014²0 & 815 & Unselected BC & TP53 p.R337H & qPCR TaqMan, sequencing, and PCR-RFLP & $70(8.6 \%)$ \\
\hline Silva et al., $2014^{14}$ & 120 & High risk BC & TP53 p.R337H & CGH-array and qPCR & $3(2.5 \%)$ \\
\hline Giacomazzi et al., $2013^{18}$ & 148 & $\begin{array}{l}\text { Phyllodes } \\
\text { tumor }\end{array}$ & TP53 p.R337H & qPCR TaqMan, sequencing & $3(2.0 \%)$ \\
\hline Assumpção et al., $2008^{19}$ & 123 & Unselected BC & $\begin{array}{l}\text { TP53 p. R337H, } \\
\text { TP53 geneexon } 10\end{array}$ & PCR-RFLP and IHC & $3(2.4 \%)$ \\
\hline Gomes et al., $2012^{21}$ & 390 & Unselected BC & TP53 p.R337H & ARMS-PCR, sequencing & $2(0.5 \%)$ \\
\hline Cury et al., 2014²2 & 28 & High risk BC & Full gene by HRM & HRM & $2(7.1 \%)$ \\
\hline Felix et al., $2014^{24}$ & 106 & High risk BC & TP53 p. R337H & AS-PCR, PCR-RFLP, sequencing & $1(0.9 \%)$ \\
\hline
\end{tabular}

HRM: high-resolution melting; qPCR: real-time polymerase chain reaction; PCR: polymerase chain reaction; RFLP: restriction fragment length polymorphism; CGH-array: comparative genomic hybridization based on microarrays; AS-PCR: allele-specific PCR; ARMS: amplification refractory mutation system; IHC: immunohistochemistry. 
group (Table 3). Two of these studies ${ }^{19,21}$ reported that the women with breast cancer who had the TP53 p.R337H mutation were under 45 years old. The third study ${ }^{22}$ described two patients with TP53 p.R337H, one diagnosed at the age of 30 and another with bilateral breast cancer, whose first cancer was detected at the age of 61, in the right breast, and the second at the age of 62, in the left breast. The data available in the selected studies did not allow a more detailed analysis of the age or clinical characteristics of patients with breast cancer and TP53 p.R337H mutation.

\section{Clinical implications in patients with the TP53 p.R337H mutation and breast cancer}

Information regarding clinical tumor characteristics, such as age at diagnosis, histological type, clinical staging, and status of immunohistochemical markers, is scarce in studies assessing the TP53 p.R337H mutation in breast cancer patients. None of them followed the patients' response after the cancer diagnosis, nor did they assess the recurrence and/or survival of those carrying the TP53 p.R337H mutation.

Regarding the age of the patients, a study carried out in Rio de Janeiro ${ }^{21}$ evaluated a series of 390 breast cancer patients, with ages ranging from 25-60 years and a mean age of 46 years at diagnosis. Two patients $(0.5 \%)$ under the age of 40 presented the TP53 p.R337H mutation, one aged 35 years and the other aged 39 years. The two patients with the TP53 p.R337H mutation reported a family history of other cancers.

The largest series of breast cancer cases selected in this review $^{20}$ investigated the prevalence of the mutation in women with breast cancer in different age groups. The study included 403 patients diagnosed with breast cancer before the age of 42 and 412 aged 55 years or older. The mean age of the patients at diagnosis was 38 (standard deviation $-\mathrm{SD}=5)$ and $66(\mathrm{SD}=9)$ years, respectively, in both groups. Invasive carcinomas were the most prevalent (90.5\%), and the genotyping performed on tumor specimens showed a prevalence of the TP53 p.R337H mutation of $8.6 \%$ in genotyped samples. The study also revealed an inverse relationship between age and mutation prevalence: in the group of women diagnosed at the age of 45 or younger, the prevalence was $12.1 \%$, while in women diagnosed at the age of 55 or older, the prevalence was $5.1 \%(\mathrm{p}<0.001)$. When women with breast cancer diagnosed at the age of 30 or younger were assessed, the prevalence of the mutation was $20 \%$ (8/40, 95\% confidence interval $-95 \% \mathrm{CI}$ 9.0-35.6\%). The analysis of TP53 p.R337H in the tumors indicated that, out of the 70 mutation-positive cases, 68 (97.1\%) were heterozygous (c.1010 AG). Only two cases had mutant alleles detected in the tumors, suggesting that the patients were constitutive mutant homozygotes or hemizygotes.

Regarding the histological type of the tumors, most studies mentioned that the TP53 p.R337H mutation-positive tumors were invasive carcinomas, without other specifications. One study ${ }^{18}$ assessed the prevalence of the TP53 p.R337H mutation in 148 women with phyllodes tumors, reporting the presence of the mutation in eight women and classifying the mutant cases as malignant $(\mathrm{n}=3)$, benign $(\mathrm{n}=5)$, and borderline $(\mathrm{n}=0)$. A malignant phyllodes tumor with the TP53 p.R337H mutation has also been described in a study developed in the Southern region of the country ${ }^{19}$.

\section{DISCUSSION}

In Southern Brazil, the germline TP53 p.R337H mutation is highly associated with pediatric adrenocortical tumors and has low penetrance and limited tumor specificity in most families presenting this mutation. Among mutation-associated tumors, breast cancer is the most frequently found in TP53 p.R337H-positive women, suggesting that this variant is relevant for breast carcinogenesis. Based on the studies included in this systematic review, the prevalence of the TP53 p.R337H mutation in Brazilian breast cancer patients is high, ranging from 0.5 to $8.6 \%$. These findings reinforce the recommendation for screening the $\mathrm{R} 337 \mathrm{H}$ variant in breast cancer patients in Brazil.

The role of the $\mathrm{R} 337 \mathrm{H}$ mutation in breast cancer is not yet clear. Most (90\%) of the germline mutations in the TP53 gene are in its DNA-binding domain. These mutations interrupt the protein structure and impair the function of the encoded protein. In contrast, the germline TP53 p.R337H mutation occurs in the p53 tetramerization domain and seems to cause a more subtle

Table 3. Case-control studies that investigated the prevalence of the TP53 p.R337H mutation in breast cancer patients.

\begin{tabular}{l|c|c|c|c} 
Reference & Type of study & $\begin{array}{c}\text { Number of cases/ } \\
\text { controls }\end{array}$ & TP53 p.R337H & Age of patients at diagnosis \\
\hline Assumpção et al., 2008 & Control case & $\begin{array}{c}123 \text { cases } \\
223 \text { controls }\end{array}$ & $\begin{array}{c}3 / 123 \\
0 / 223\end{array}$ & $\begin{array}{c}19 \text { years, 29 years, and } 44 \text { years } \\
\text { Mean age: } 30.6 \text { years }\end{array}$ \\
\hline Gomes et al., 2012 & Control case & $\begin{array}{c}390 \text { cases } \\
324 \text { controls }\end{array}$ & $\begin{array}{c}2 / 390 \\
0 / 324\end{array}$ & $\begin{array}{c}35 \text { years and 39 years } \\
\text { Mean age: } 37 \text { years }\end{array}$ \\
\hline Cury et al., 201422 & Control case & $\begin{array}{c}28 \text { cases } \\
120 \text { controls }\end{array}$ & $\begin{array}{c}2 / 28 \\
0 / 120\end{array}$ & $\begin{array}{c}30 \text { years, } 61 \text { years (left breast), } \\
\text { and } 62 \text { years (right breast) } \\
\text { Mean age: } 45.5 \text { years }\end{array}$ \\
\hline
\end{tabular}


defect in the protein, which becomes functionally deficient only under certain conditions.

Germline TP53 mutations are related to the Li-Fraumeni syndrome (LFS) with cancer predisposition. Individuals with germline TP53 mutations have two characteristic disease phases, one in childhood with a tendency to develop rare cancers and one in adulthood with a tendency to develop more common cancers, but with early onset. The risk of childhood cancer versus adult cancer depends on the type of TP53 mutation, as well as on genetic modifiers, including polymorphisms in TP53 and genes encoding p53 regulators, such as murine double minute 2 (Mdm2), among others'.

A recent study used a full genome sequencing to analyze a $2 \mathrm{Mb}$ region at the TP53 locus in samples of adrenocortical carcinomas. Selected common and rare variants were genotyped in 204 TP53 p.R337H-positive cancer patients and a control group of 67,359 newborns. A commonly shared haplotype containing the E134* variant of the XAF1 gene was detected in a subgroup (42\%) of patients with adrenocortical carcinomas. This rare variant was identified in $70 \%$ of patients with TP53 p.R337H. The cosegregation of both variants was found in $79 \%$ of cancer patients and was significantly higher in individuals with sarcoma and multiple malignancies, including breast cancer ${ }^{23}$. The results of this study should be expanded and may contribute to elucidate the role of the TP53 $\mathrm{R} 337 \mathrm{H}$ mutation and its modifiers.

The studies included in this review were conducted in the states of São Paulo, Rio de Janeiro, Rio Grande do Sul, and Bahia. São Paulo and Rio Grande do Sul had the largest number of publications on the subject, and the highest prevalence of TP53 p.R337H mutation in women with breast cancer was found in Porto Alegre (8.6\%) and Ribeirão Preto (7.1 \%). A study carried out in Bahia showed that one out of 106 women with breast cancer assessed had the TP53 p.R337H mutation, indicating that the mutation is not restricted to the South and Southeast regions ${ }^{24}$.

One of the studies included in the systematic review ${ }^{20}$ investigated the prevalence of the TP53p.R337H mutation in a large group of breast cancer patients from three important reference centers for cancer treatment in Brazil and performed the geographical distribution of the cases assessed. The study revealed a significant variation in the disposition of breast cancer cases with the TP53p.R337H mutation. This variation can be explained by the differential dissemination of the founder haplotype in some regions of the country due to the migratory effect and sociodemographic differences that intrinsically affect the risk of developing breast cancer in the Brazilian population. The lack of studies in different geographic regions of Brazil demands the development of new research on this subject.

The studies included in this article used several methods to detect the TP53 p.R337H mutation, especially PCR-RFLP and qPCR with TaqMan probes. An investigation that assessed 95 genomic DNA samples compared the performance, cost, and response time of the Sanger, PCR-RFLP, TaqMan-PCR, and HRM sequencing methods employed in the TP53 p.R337H genotyping, and the results were $100 \%$ concordant for all methods ${ }^{25}$. Nonetheless, DNA sequencing is considered the gold standard among the methods and recommended to confirm the mutation.

This systematic review included three case-control studies $^{19,21,22}$. The TP53 p.R337H mutation was detected in seven of the 541 patients in the case group (1.3\%), and none of the 667 women in the control group. Despite the considerable number of cases evaluated, the heterogeneity of the studies did not allow a combined analysis of the data in the form of meta-analysis, which prevented the assessment of the risk of TP53 p.R337H-positive patients developing breast cancer.

An important limitation of this study is the fact that prognostic aspects of TP53 p.R337H-positive breast cancer could not be assessed since none of the included articles addressed these variables. Retrospective studies that include large series and the possibility of patient follow-up are necessary to elucidate the prognostic role of the TP53 p.R337H mutation in breast cancer.

As described in the "Results" section, information regarding clinical tumor characteristics, such as their histological type, clinical staging, and status of immunohistochemical markers, was extremely scarce in the studies included in this work. Immunohistochemical data from 66 breast cancer patients positive for TP53 p.R337H were reviewed and compared to data from 12 patients with other functional TP53 mutations ${ }^{26}$. In the group of patients with other functional TP53 mutations, $75 \%$ of the tumors showed overexpression of HER2 (3+), corroborating previous studies, while $22.7 \%$ of the patients with TP53 p.R337H presented HER2 overexpression. These results reinforce the hypothesis that different germline TP53 mutations act through different pathways of carcinogenesis, suggesting that the histopathological and immunohistochemical aspects of TP53 p.R337H-positive breast cancer should be further investigated in future studies.

The seven studies included in this review showed that 87 (4.8\%) of the 1,789 women with breast cancer investigated in Brazil had the TP53 p.R337H mutation. These results indicate that the TP53 p.R337H variant contributes to an important portion of breast cancers diagnosed in our population and that screening for this variant needs to be considered in the diagnosis and prevention of these tumors. The prevalence of the TP53 p.R337H variant is high when compared to other particular mutations detected in TP53 and should be taken into account in the genetic counseling of Brazilian breast cancer patients.

\section{AUTHORS' CONTRIBUTIONS}

V.A.S.: Conceptualization, funding acquisition, investigation, methodology, investigation, project administration, supervision, validation, visualization, writing - review \& editing.

D.C.A.: investigation, validation, visualization, writing - review \& editing. 
E.S.V.C.: Data curation, formal analysis, Investigation, writing - original draft.

I.F.M.: Data curation, formal analysis, investigation, writing original draft.
N.A.N.: Conceptualization, data curation, formal analysis, investigation, visualization, writing - original draft, writing - review \& editing.

F.M.A.: Methodology, validation, writing - review \& editing.

\section{REFERENCES}

1. Hoadley KA, Yau C, Wolf DM, Cherniack AD, Tamborero D, $\mathrm{Ng} \mathrm{S}$, et al. Multiplatform analysis of 12 cancer types reveals molecular classification within and across tissues of origin. Cell. 2014;158(4):929-44. https://doi.org/10.1016/j.cell.2014.06.049

2. Shah SP, Roth A, Goya R, Oloumi A, Ha G, Zhao Y, et al. The clonal and mutational evolution spectrum of primary triple-negative breast cancers. Nature. 2012;486(7403):395-9. https://doi.org/10.1038/nature10933

3. Silwal-Pandit L, Vollan HK, Chin SF, Rueda OM, McKinney $\mathrm{S}$, Osako T, et al. TP53 mutation spectrum in breast cancer is subtype specific and has distinct prognostic relevance. Clin Cancer Res. 2014;20(13):3569-80. https://doi. org/10.1158/1078-0432.CCR-13-2943

4. Nik-Zainal S, Davies H, Staaf J, Ramakrishna M, Glodzik D, Zou X, et al. Landscape of somatic mutations in 560 breast cancer whole-genome sequences. Nature. 2016;534(7605):4754. https://doi.org/10.1038/nature17676

5. HahnEC, Bittar CM, ViannaFSL, Netto CBO, BiazúsJV, Cericatto $\mathrm{R}$, et al. TP53 p. Arg337His germline mutation prevalence in Southern Brazil: Further evidence for mutation testing in young breast cancer patients. PLoS One. 2018;13(12):e0209934. https:// doi.org/10.1371/journal.pone.0209934

6. Levine AJ, Oren M. The first 30 years of p53: growing ever more complex. Nat Rev Cancer. 2009;9(10):749-58. https://doi. org/10.1038/nrc2723

7. Levine AJ. The many faces of p53: something for everyone. J Mol Cell Biol. 2019;11(7):524-30. https://doi.org/10.1093/jmcb/mjz026

8. Wasserman JD, Zambetti GP, Malkin D. Towards an understanding of the role of p53 in adrenocortical carcinogenesis. Mol Cell Endocrinol. 2012;351(1):101-10. https://dx.doi.org/10.1016\%2Fj.mce.2011.09.010

9. Blandino G,DeppertW,HainautP,LevineA,Lozano G,Olivier M, et al. Mutant p53 protein, master regulator of human malignancies: a report on the Fifth Mutant p53Workshop. Cell Death Differ. 2012;19(1):180-3. https://dx.doi.org/10.1038\%2Fcdd.2011.148

10. Latronico AC, Pinto EM, Domenice S, Fragoso MC, Martin RM, Zerbini MC, et al. An inherited mutation outside the highly conserved DNA-binding domain of the p53 tumor suppressor protein in children and adults with sporadic adrenocortical tumors. J Clin Endocrinol Metab. 2001;86(10):4970-3. https:// doi.org/10.1210/jcem.86.10.7957

11. Ribeiro RC, Sandrini F, Figueiredo B, Zambetti GP, Michalkiewicz E, Lafferty AR, et al. An inherited p53 mutation that contributes in a tissue-specific manner to pediatric adrenal cortical carcinoma. Proc Natl Acad Sci. 2001;98(16):9330-5. https://doi.org/10.1073/pnas.161479898
12. Digiammarino EL, Lee AS, Cadwell C, Zhang W, Bothner B, Ribeiro RC, et al. A novel mecanism of tumorigenis involving pH-dependent destabilization of a mutant p53 tetramer. Nat Struct Biol. 2002;9(1):12-6. https://doi.org/10.1038/nsb730

13. Macedo GS, da Motta LL, Giacomazzi J, Netto CBO, Manfredini V, Vanzin CS, et al. Increased Oxidative Damage in Carriers of the Germline TP53p.R337H Mutation. PLoS One. 2012;7(10):e47010. https://doi.org/10.1371/journal.pone.0047010

14. Silva FC, Lisboa BCG, Figueiredo MCP, Torrezan GT, Santos EMM, Krepischi AC, et al. Hereditary breast and ovarian cancer: assessment of point mutations and copy number variations in Brazilian patients. BMC Med Genet. 2014;15:55. https://doi.org/10.1186/1471-2350-15-55

15. Garritano S, Gemignani F, Palmero EI, Olivier M, Martel-Planche G, Le Calvez-Kelm F, et al. Detailed Haplotype Analysis at the TP53 Locus in p.R337H Mutation Carriers in the Population of Southerns Brazil: Evidence for a Founder Effect. Hum Mutat. 2010;31(2):143-50. https://doi.org/10.1002/humu.21151

16. Achatz MI, Olivier M, Le Calvez F, Martel-Planche G, Lopes A, Rossi $\mathrm{B}$, et al. The TP53 mutation, R337H, is associated with Li-Fraumeni and Li-Fraumeni-like syndromes in Brazilian families. Cancer Lett. 2007;245(1-2):96-102. https://doi.org/10.1016/j.canlet.2005.12.039

17. Borges LM, Ayres FM. R337H mutation of the TP53 gene as a clinical marker in cancer patients: a systematic review of literature. Genet Mol Res. 2015;14(4):17034-43. https://doi. org/10.4238/2015.December.16.4

18. Giacomazzi J, Koehler-Santos P, Palmero EI, Graudenz MS, Rivero LF, Lima E, et al. A TP53 founder mutation, p.R337H, is associated with phyllodes breast tumors in Brazil. Virchows Arch. 2013;463(1):17-22. https://doi.org/10.1007/s00428-013-1439-8

19. Assumpção JG, Seidinger AL, Mastellaro MJ, Ribeiro RC, Zambetti GP, Ganti R, et al. Association of the germline TP53 R337H mutation with breast cancer in southern Brazil. BMC Cancer. 2008;8:357. https://doi.org/10.1186/1471-2407-8-357

20. Giacomazzi J, Graudenz MS, Osorio CA, Koehler-Santos P, Palmero EI, Zagonel-Oliveira M, et al. Prevalence of the TP53 p.R337H mutation in breast cancer patients in Brazil. PLoS One. 2014;9(6):e99893. https://doi.org/10.1371/journal.pone.0099893

21. Gomes MC, Kotsopoulos J, de Almeida GL, Costa MM, Vieira R, Filho AGF, et al. The R337H mutation in TP53 and breast cancer in Brazil. Hered Cancer Clin Pract. 2012;10(1):3. https:// dx.doi.org/10.1186\%2F1897-4287-10-3

22. Cury NM, Ferraz VEF, Silva WA Jr. TP53 p.R337H prevalence in a series of Brazilian hereditary breast cancer families. Hered Cancer Clin Pract. 2014;12(1):8. https://doi.org/10.1186/18974287-12-8 
23. PintoE,FigueiredoB, GalvãoH,Fragoso M,RibeiroE,Diekmann Y, et al. SAT-LB058 Effect of a Genetic Modifier of Cancer Risk in TP53 Mutation Carriers. J Endocr Soc. 2019;3(Supl. 1):SATLB058. https://dx.doi.org/10.1210\%2Fjs.2019-SAT-LB058

24. Felix GE, Abe-Sandes C, Machado-Lopes TMB, Bomfim TF, Guindalini RSC, Santos VCS, et al. Germline mutations in BRCA1, BRCA2, CHEK2 and TP53 in patients at highrisk for HBOC: characterizing a Northeast Brazilian Population. Hum Genome Var. 2014;1:14012. https://dx.doi. org/10.1038\%2Fhgv.2014.12
25. Fitarelli-Kiehl M, Macedo GS, Schlatter RP, Koehler-Santos P, Matte Uda S, Ashton-Prolla P, et al. Comparison of multiple genotyping methods for the identification of the cancer predisposing founder mutation p.R337H in TP53. Genet Mol Biol. 2016;39(2):203-9. https://doi.org/10.1590/1678-4685-GMB-2014-0351

26. Fitarelli-Kiehl M, Giacomazzi J, Santos-Silva P, Graudenz MS, Palmero EI, Michelli RAD, et al. The breast cancer immunophenotype of TP53-p. R337H carriers is different from that observed among other pathogenic TP53 mutation carriers. Fam Cancer. 2015;14(2):333-6. https://doi.org/10.1007/s10689-015-9779-y 